\title{
軸圧縮力が作用する薄肉八角形断面部材の局部座屈耐力 \\ LOCAL BUCKLING STRENGTH OF UNIFORMLY COMPRESSED OCTAGONAL THIN WALLED SECTION MEMBERS
}

\author{
小橋知 季*1, 中安誠明*2, 清 水信 孝*2, 菅野良一 ${ }^{* 3}$, 五十嵐 規矩夫*4 \\ Tomoki KOBASHI, Nariaki NAKAYASU, Nobutaka SHIMIZU, \\ Ryoichi KANNO and Kikuo IKARASHI
}

\begin{abstract}
Cold-formed steel members are widely applied in columns and other axial members in steel structures. One of the key issues in design of cold formed steel is local buckling strength under axial compression. As a means to avoid premature local buckling, we have paid an attention to the application of octagonal section members. In this paper, we conducted numerical analyses (Finite Strip Analysis and Finite Element Analysis) and stab column tests, to investigate both the elastic and the post buckling strengths of octagonal section members including those where the adjacent plate elements have different width-thickness ratios. These tests and numerical analysis results indicated that the post buckling strengths of the plate elements were affected by the restraining effect from the adjacent plate elements. However, the overall strengths of the members were in line with those estimations by the traditional effective-width method, where simply supported conditions were assumed. This was caused possibly by a trade-off effect between the adjacent plate elements on their local buckling strengths.
\end{abstract}

Keymords: Octagonal Section M embers, Cold Formed Steel, Elastic Local Buckling Strength, Post Buckling Strength 八角形断面，薄板軽量形鋼，弾性局部座屈而力，座屈後耐力

1. 序

薄板軽量形鋼造 ${ }^{1)}$ は，板厚 $0.4 \mathrm{~mm}$ 以上 $2.3 \mathrm{~mm}$ 未満の薄鋼板を冷 間成形した形鋼を構造耐力上の主要部分に用いた構造であり，スチ 一ルハウス等の壁式工法建築物で使用されている構造形式である. これらの建物では, 板状の面材とその 4 辺を固定する枠材をねじで 組み立てたパネル部材で主要な構造部材が構成されており，地震荷 重や風荷重などのパネル部材が負担する層せん断力は, 四辺を固定 する枠材に軸力として伝達され，基礎へと伝わる荷重伝達機構を有 する.ゆえに薄板軽量形鋼造の建物において, 枠材はパネル部材が 終局状態に至るまで損傷することなく健全な状態を保持する必要が あり，高い軸力の負担が期待できる仕様とすることが求められる。 一方で，薄板軽量形鋼は部材断面を構成する板要素の幅厚比が大き いため, 圧縮力が作用すると素材降伏に至る前に板要素に局部座屈 が発生するという特徴がある ${ }^{2)}$ 。この局部座屈の抑制に向けて, リ ブ付与により座屈を補剛する対策を取る場合があるが, 展開長や加 工手間の増加に繋がるため不経済な設計を招くという課題がある. 展開長や加工手間の増加を招くことなく部材の局部座屈耐力を高 める方法の一つとして, 八角形断面の適用が考えられる. 八角形断
面を有する閉断面部材は，溝形鋼などの開断面部材と比較して高い ねじり剛性を有し，等しい部材幅を有する正方形断面部材よりも断 面を構成する板要素の幅厚比が小さくなるという特徵がある。この ため薄板軽量形鋼のように部材断面を構成する板要素に弾性局部座 屈が生じうる部材では，高い部材耐力の発揮が期待できる.

八角形断面を有寸る部材の局部座屈耐力に関する研究には, Bulson $^{3)}$, 右田 ${ }^{4)}$, 小瀬古 ${ }^{5)}$ の実験的研究や, Teng6)の理論的研究な どがあり，軸圧縮力が作用する正八角形断面部材の座屈挙動につい ては概ね明らかにされていると言える. Bulson は，正 $4 \sim 40$ 角形 断面を有する閉断面部材（幅厚比：56～790）の圧縮実験を行い, 正 4〜18 角形断面を有する部材において, 断面を構成する板要素を すべて単純支持板とみなし各板要素の座屈後耐力を単純累加するこ とで，部材の最大耐力を評価できることを示した．Teng は，正 4〜 正 8 角形断面を有する部材の座屈固有值解析を行い, 軸圧縮条件下 において, 正 8 角形断面を有する部材の弾性局部座屈耐力は板要素 の幅厚比が等しい正方形および正六角形の弾性局部座屈耐力と等し くなり，なおかつこの弾性局部座屈耐力が同じ幅厚比を有する単純 支持板の弾性局部座屈耐力と等しいことを示した，右田は，幅厚比
*1 新日鐵住金(株鋼構造研究部 修士 (工学) 東京工業大学大学院理工学研究科建築学専攻 博士後期課程 (社会人コース)

*2 新日鐵住金株鋼構造研究部 主幹研究員 ·博士 (工学)

*3 新日鐵住金(侏)技術開発本部 フェロー・Ph. D.

*4 東京工業大学環境・社会理工学院建築学系 准教授・博士 (工学)

\footnotetext{
Steel Structures Research Lab., Nippon Steel \& Sumitomo Metal Corporation, M. Eng. Grad. Student, Dept. of Architecture and Building Engineering, Tokyo Institute of Technology

Senior Researcher, Steel Structures Research Lab., Nippon Steel \& Sumitomo Metal Corporation, Dr. Eng.

Fellow, Research \& Development Center, Nippon Steel \& Sumitomo Metal

Corporation, Ph. D.

Assoc. Prof., Dept. of Architecture and Building Engineering, Tokyo Institute of

Technology, Dr. Eng.
} 
が 33.3〜 66.7 の正 4〜正 8 角形断面部材の圧縮実験を行い, 実験的 な耐力評価式を提案した。

また八角形断面の部材では断面形状が必ずしも正八角形であると は限らず，隣り合う辺の長さが異なる場合も考えられる，小瀬古 5) は最大幅厚比が 18.4〜 51.3 の扁平な八角形断面を有する部材の単 柱圧縮実験を行い, 軸圧縮条件下においては扁平断面を有する八角 形部材よりも正八角形断面を有する部材の方が構造的に有利である とした. しかし, このような正八角形ではない八角形の断面を有す る部材の挙動に関する研究例は文献 5) 以外の研究例は見当たらず, その力学挙動について十分な知見が得られているとは言い難い. 例 えば，正多角形断面では軸圧縮条件下において断面を構成する板要 素が各々単純支持板のように挙動するのに対して ${ }^{33,6)}$, 隣り合う辺 の板要素の幅が異なる八角形断面では, 幅の大きい板要素が幅の小 さい板要素によって拘束されることで, 板要素板側辺部に回転抵抗 が生じて単純支持とは異なる境界条件になると考えられる。しかし ながら, 正八角形以外の八角形断面について, 断面形状と局部座屈 耐力の関係を明らかにした研究例は無い。また, 隣接する板要素の 幅が異なる場合, 断面を構成する板要素が各々の最大耐力に到達し た後は, 変形の増加と共に負担耐力が低下寸ることから, 全ての板 要素が同時に最大耐力を迎えない限り, 厳密には板要素の最大耐力 を単純累加することはできない 7). ゆえに, 断面を構成する板要素 を単純支持板とみなして部材耐力を評価する既往の設計耐力と八角 形断面の実性能との対応は, 実験や解析を通じて明らかにする必要 がある。

本研究では, 軸圧縮力が作用する八角形断面部材について, 扁平 ではない 90 度の回転対称の断面を有する八角形断面部材の座屈耐 力を明らかにする。 まず，等しい部材幅を有する正方形断面および 八角形断面部材の座屈固有值解析を行い, 部材の断面形状が弾性局 部座屈耐力に及ぼす影響を明らかにする. 次に, 隣り合う板要素の 幅が異なる八角形断面部材について弾性座屈後の最大耐力を実験で 定量化し，板要素を全て単純支持板とみなした既往設計指針に基づ く計算耐力との対応関係について言及する. 最後に, 有限要素解析 によって最大耐力時に板要素が負担する軸力を定量化し, 隣り合う 板要素の幅の違いが板要素の負担軸力に与える影響を明らかにする.

\section{2. 有限帯板法による座屈固有值解析}

ここでは, 有限帯板法(Finite Strip Method)による固有值解析 (FSA) 8),9)を行い, 部材の断面形状の違いが弾性局部座屈耐力に及ぼ す影響を分析する. 正方形および八角形断面を有する部材の局部座 屈モードを整理し, 部材の弾性局部座屈耐力と単純支持板の弾性局 部座屈耐力との比較を通じて, 隣り合う板要素の幅厚比の違いが部 材の弾性局部座屈耐力に及ぼす影響を明らかにする.

\section{1. 有限帯板法による座屈固有值解析}

有限帯板法による固有值解析ソフト CU-FSM ${ }^{8)}$ を使用して, 八角 形断面部材の弾性局部座屈耐力と断面形状の関係について検討した. 解析対象は, 部材幅 $D(=100 \mathrm{~mm})$, 板厚 $t(=0.8 \mathrm{~mm})$ の正方形断面 および八角形断面を有する閉断面部材である(図 1). 軸力部材を想定 し, 断面内に一様な軸圧縮応力が作用する部材の座屈固有值を解析 で求めた，解析モデルは，断面を構成する各板要素を各々板幅方向 に 8 等分した断面形状を有する. 部材両端部の境界条件はピン支持
である，各々の板要素に生じる弾性座屈の波形を，材軸方向では正 弦関数半波に，材軸と直交する方向では 3 次の多項式にそれぞれ近 似のうえ ${ }^{8)}$, 部材長を $10 \mathrm{~mm}$ から $5000 \mathrm{~mm}$ まで変化させた固有值 解析を実施し, 弾性局部座屈耐力を求めた。解析のパラメータは部 材の断面形状であり, 角部の幅 $W($ 図 $1(\mathrm{~d}))$ を $0 \mathrm{~mm}$ から $29 \mathrm{~mm}$ まで $1 \mathrm{~mm}$ きざみで変化させた，材料には引張強度が $400 \mathrm{~N} / \mathrm{mm}^{2}$ 級の鋼 を想定し, ヤング係数 $E=205 \times 10^{3} \mathrm{~N} / \mathrm{mm}^{2}$, ポアソン比 $v=0.3$, 降伏 态力 $\sigma_{y}=280 \mathrm{~N} / \mathrm{mm}^{2}$ とした.

\section{2. 単純支持板の弾性局部座屈耐力と解析結果の比較}

解析より得られた座屈モードを図 2 に示寸. 図から, 本解析では 隣り合う板要素間の接合線が回転して各板要素が面外方向へ凹凸に 変形する座屈(局部座屈)のモードと, 接合線の水平移動と回転が連 成する座屈(ゆがみ座屈)のモードが生じたことが分かる．正方形断 面では, 接合線が回転して隣り合う板要素が交互に凹凸に変形する 局部座屈のモードが発現し, 接合線の移動は生じなかった(図 2(a)). 八角形断面では, 角部の幅 $W$ が非常に小さい八角形断面 $(w / D=0.03)$ では, 接合線の水平移動と回転が連成するゆがみ座屈モードが生じ (図 $2(\mathrm{~b})$ ), 角部の幅が大きくなると $(w / D=0.10)$ 接合線の水平移動が 抑制されて,ゆがみ座屈から局部座屈へと座屈モードが変化した(図 $2(\mathrm{c})$ ). 正八角形断面 $(w / D=0.29)$ の座屈モードは, 基本的に $w / D=0.10$ と同様であり, 接合線の移動を伴うこと無く接合線の回転のみが生 じる局部座屈の座屈モードであった（図 $2(\mathrm{~d})$ ).

$\sigma_{c r} \sigma_{y}\left(\mathrm{FSA}\right.$ より得た弾性座屈耐力 $\sigma_{c r}$ を材料の降伏応力 $\sigma_{y}$ で無次 元化した值)と $b_{1} / t\left(b_{1}\right.$ は幅の大きい板要素の幅)の関係を図 3 に示す 図中のプロットは FSA による解析值を示し, 実線は, 次式(式(1)) によって表される弾性局部座屈耐力 $\sigma_{c r, k=4}$ である。 (1), (2), (3), (4) は, 各々図 4 の(1), (2), (3), (4)と対応している. 断面内の板要素の 中で最大幅を有する要素が最初に座屈するため, 幅の大きい板要素 の幅を板幅 $b_{1}$ の単純支持板 $(k=4)$ とみなして弾性局部座屈耐力を計 算した。

$$
\sigma_{\mathrm{cr}, \mathrm{k}=4}=\mathrm{k} \frac{\mathrm{E} \pi^{2}}{12\left(1-v^{2}\right)}\left(\frac{\mathrm{t}}{\mathrm{b}_{1}}\right)^{2}=\frac{\mathrm{E} \pi^{2}}{3\left(1-v^{2}\right)}\left(\frac{\mathrm{t}}{\mathrm{b}_{1}}\right)^{2}
$$

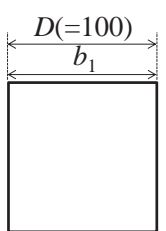

(a) $w / D=0$

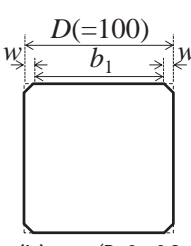

(b) $w / D=0.03$

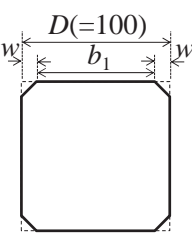

(c) $w / D=0.10$

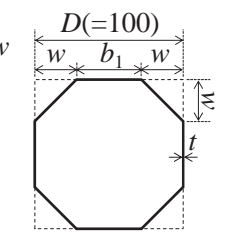

(d) $w / D=0.29$
図 1 座屈固有值解析モデルの断面形状

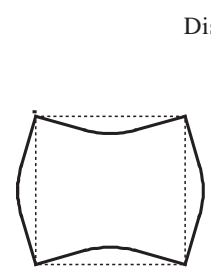

(a) $w / D=0$

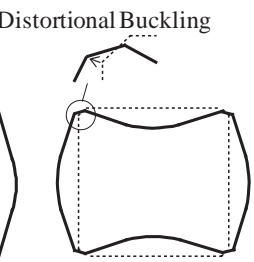

(b) $w / D=0.03$

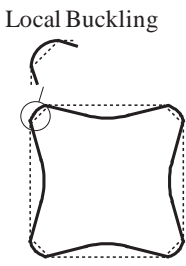

(c) $w / D=0.10$

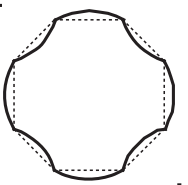

(d) $w / D=0.29$
図 2 座屈固有值解析における局部座屈モード 
図から, 隣り合う板要素の幅が等しい正方形断面(図 2(a)) と正八 角形断面(図 2(d))の弾性局部座屈耐力は単純支持された板要素の座 屈耐力(式(1))と等しいことが分かる. 一方, 隣り合う板要素の幅が 異なる八角形断面の場合(例えば, 図 2(c)など)では, 単純支持板の 弾性局部座屈耐力に対して解析值が全般的に大きめの耐力を与えた. このような弾性座屈耐力の変化を考察するために, $W D$ (部材幅 $D$ に対する角部の幅 $W$ の比率) と $\sigma_{\mathrm{cr}} / \sigma_{c r, k=4}(\mathrm{FSM}$ で計算した座屈固有 值 $\sigma_{c r}$ を単純支持板の弾性局部座屈耐力 $\sigma_{c r, k=4}$ で除した值）の関係を 図 4 に示す. 図から， $\sigma_{c r} / \sigma_{c r, k=4}$ は断面形状（wDにより変化）の影 響を強く受けていることが確認できる. 正方形断面（図 4 中(1)の線： $W / D=0)$ では $\sigma_{c r} / \sigma_{c r, k=4}$ は 1 であるが, 角部幅 $W$ が非常に小さいケー

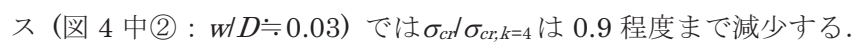
ここから角部幅 $W$ を大きくすると（図 4 中(3): $W D \fallingdotseq 0.10$ ), $\sigma_{c r} / \sigma_{c r, h=4}$ は逆に 1.45 程度まで上昇し, 正八角形断面（図 4 中(4)：W $D \fallingdotseq 0.29$ ) になると $\sigma_{c r} / \sigma_{c r, k=4}$ は再び 1 に近づく.

正方形断面および正八角形断面の座屈モード（図 2(a)，2(d)）を 見ると, 板要素間の接合線が移動すること無く回転している様子が 分かる.これらの隣り合う板要素の幅が等しい断面では, 隣り合う 板要素同士が相互に影響を及ぼすことなく接合線が回転するため,

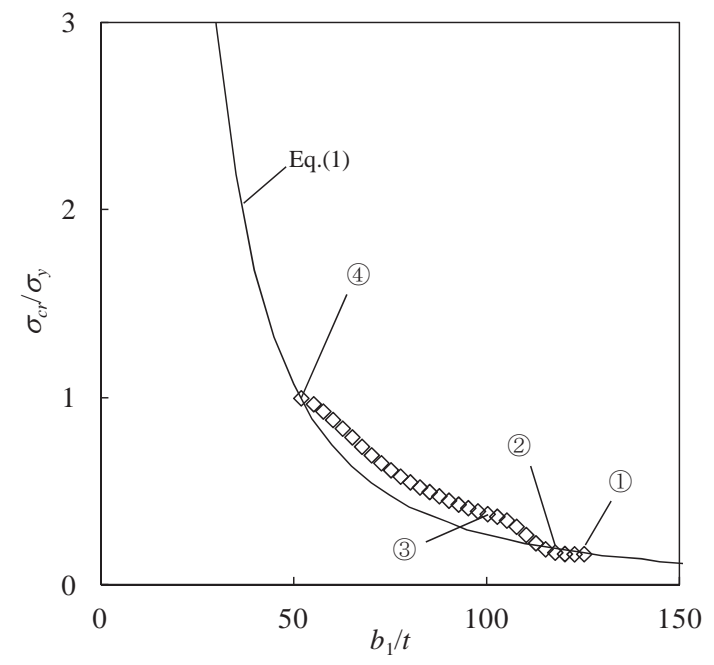

図 3 単純支持条件の弾性局部座屈耐力との比較

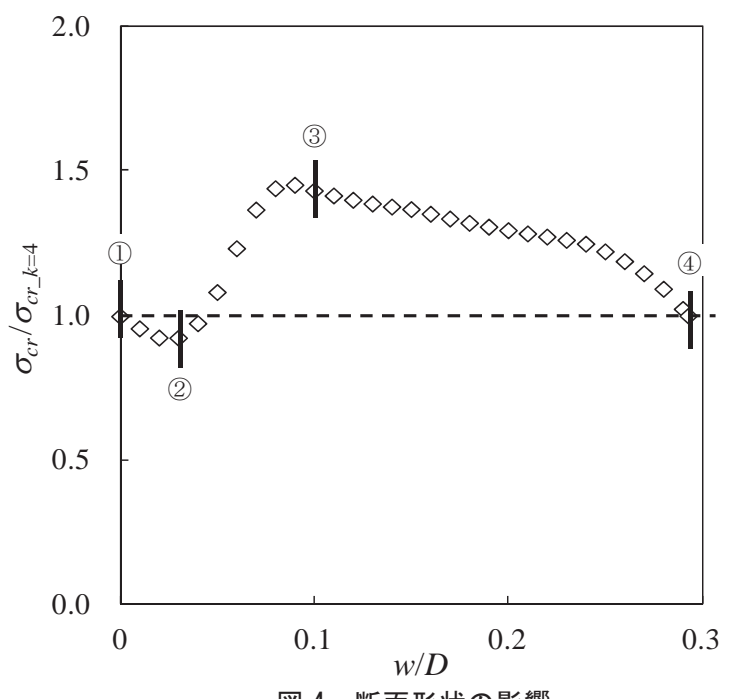

図 4 断面形状の影響
各板要素の境界条件は単純支持とみなすことができ， $\sigma_{c r}$ は $\sigma_{c r, k=4}$ と 同じ值になった。隣り合う辺の長さが異なる八角形断面のうち, $\sigma_{c t} / \sigma_{c r, k=4}$ が 1 よりも大きくなる(3)のースについては，接合線の移 動を生じることなく接合線が回転し，幅厚比の大きい板要素と幅厚 比の小さい板要素が凹凸に変形している (図 $2(\mathrm{c})$ ). 隣り合う板要素 の幅厚比が異なる場合, 幅厚比の大きい板要素は幅厚比の小さい板 要素によって拘束される。その結果，局部座屈が生ずる幅厚比の大 きい板要素の側辺部（幅厚比の小さい板要素との接合線）に回転抵 抗が生じ，弾性座屈耐力が板要素を単純支持板とみなした場合より も大きくなる， $\sigma_{c r} / \sigma_{c r, k=4}$ が 1 より低くなった(2)のケースでは，接合 線の移動を伴う座屈が生じていることが分かり，座屈モードが局部 座屈からゆが夕座屈へと変化したことで弾性局部座屈耐力の低下が 生じたものと考えられる。

\section{3. 八角形断面を有する薄板部材の座屈後耐力}

2 章では, 隣り合う板要素の幅が異なる八角形断面部材の弾性局 部座屈耐力が，断面を構成する板要素を単純支持板とみなした場合 の理論的な弾性局部座屈耐力よりも高くなり得ることを示した。本 章では，八角形断面を有する部材の短柱圧縮実験を行い，隣り合う 板要素の幅が異なる八角形断面部材について，弾性局部座屈後の最 大耐力（座屈後耐力）を定量化するとともに，板要素を全て単純支

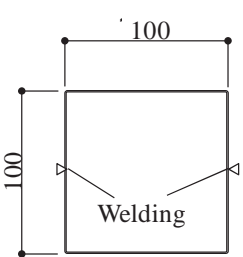

(a) $\mathrm{SQ}-00$

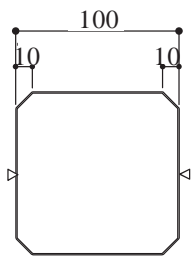

(c) $0 \mathrm{ct}-10$

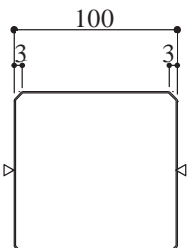

(b) $0 \mathrm{ct}-03$

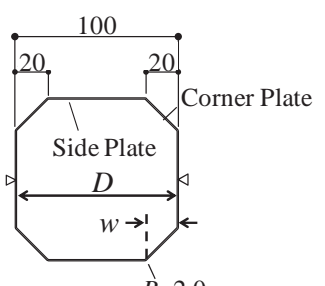

(d) 0 ct-20

図 5 試験体図

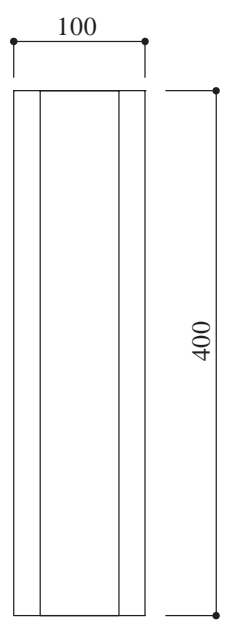

(e) 立面図

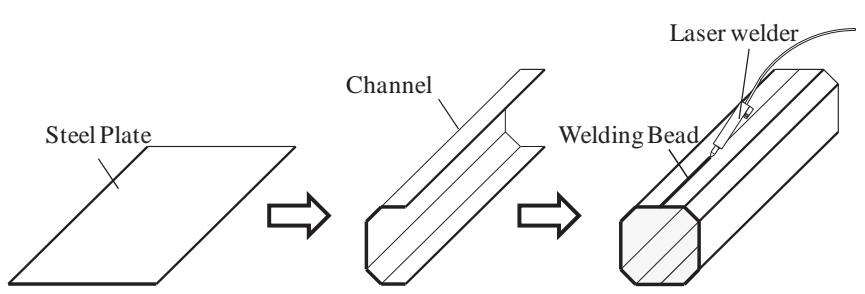

(a) 平板 (b) 曲げ加工

（c）溶接組立

図 6 試験体製作工程

\section{表 1 材料試験結果}

\begin{tabular}{|c|c|c|c|c|c|}
\hline $\begin{array}{c}\text { Plate Thickness } \\
(\mathrm{mm})\end{array}$ & $\begin{array}{c}0.1 \% \text { Offset } \\
\text { Stress (M Pa) }\end{array}$ & $\begin{array}{c}0.2 \% \text { Offset } \\
\text { Stress (M Pa) }\end{array}$ & $\begin{array}{c}\text { Tensile Strength } \\
(\mathrm{M} \mathrm{Pa})\end{array}$ & $\begin{array}{c}\text { Yield Ratio } \\
(\%)\end{array}$ & $\begin{array}{c}\text { Elongation } \\
(\%)\end{array}$ \\
\hline \hline 0.813 & 315 & 331 & 439 & 75.1 & 33 \\
\hline
\end{tabular}



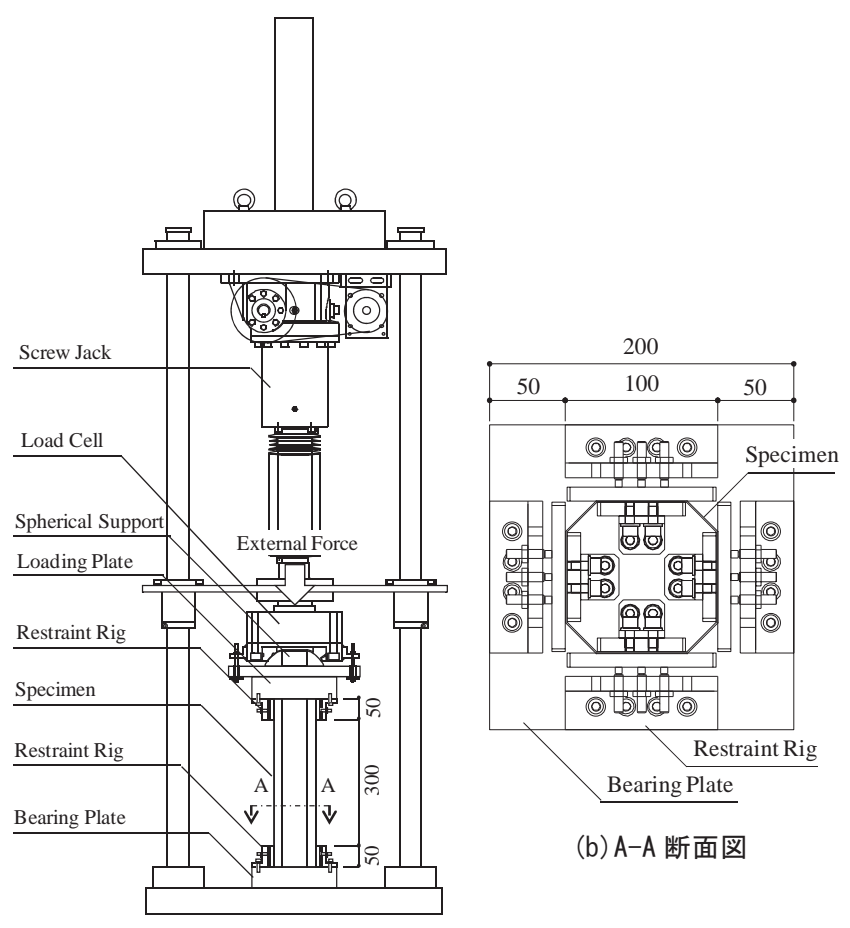

(b) A-A 断面図

(a) 立面図

図 7 セットアップ概要

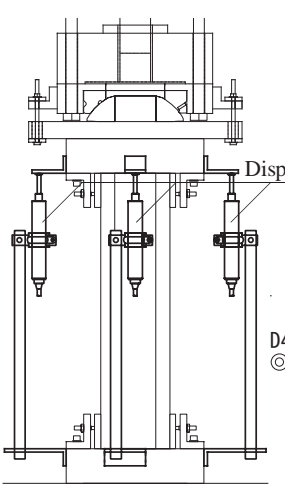

（a）変位計測

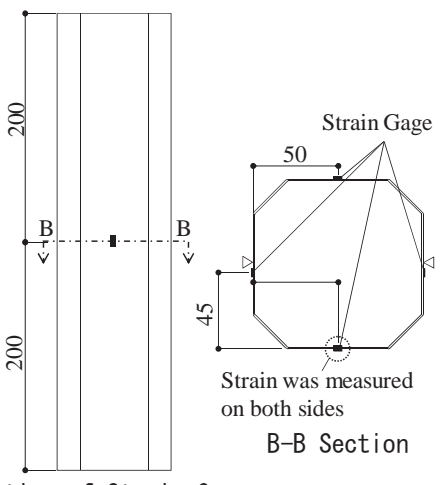

Position of Strain Gauges

(b) ひずみ計測

図 8 計測計画

持板とみな寸既往の設計指針に基づく計算耐力と部材の最大耐力と の対応関係を明らかにする.

\section{1. 試験概要}

図 5 には, 試験体の断面図と立面図を示す. 本実験では, 試験体 の部材幅 $D(=100 \mathrm{~mm})$ と部材長さ $L(=400 \mathrm{~mm})$ が一定で角部幅 $W$ を変化させた 4 体の試験体を用いて実験を行った，SQ-00 は ${ }_{W=0 \mathrm{~mm}}$ の正方形断面を有する試験体である. 隣接する板要素の幅 厚比が全て等しく, 断面を構成する板要素の端部境界条件はピン支

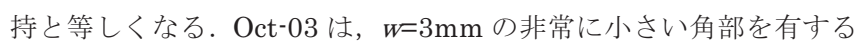
試験体であり, 角部の回転を伴うゆがみ座屈（図 2(b)）の発生を想 定している. Oct-10 と Oct- 20 は各々 $w=10 \mathrm{~mm}$ と $w=20 \mathrm{~mm}$ の角部 を有する試験体である. 隣接する板要素の幅を変化させることで, 幅の大きい板要素（side plate）の側辺部の回転変形を幅の小さい 板要素 (corner plate) で拘束している.

図 6 には, 試験体の製作工程を示す.まず 2 枚の鋼板を用意し, 各試験体とも折曲げ円弧部の最外縁の曲げ半径が $2.0 \mathrm{~mm}$ になるよ
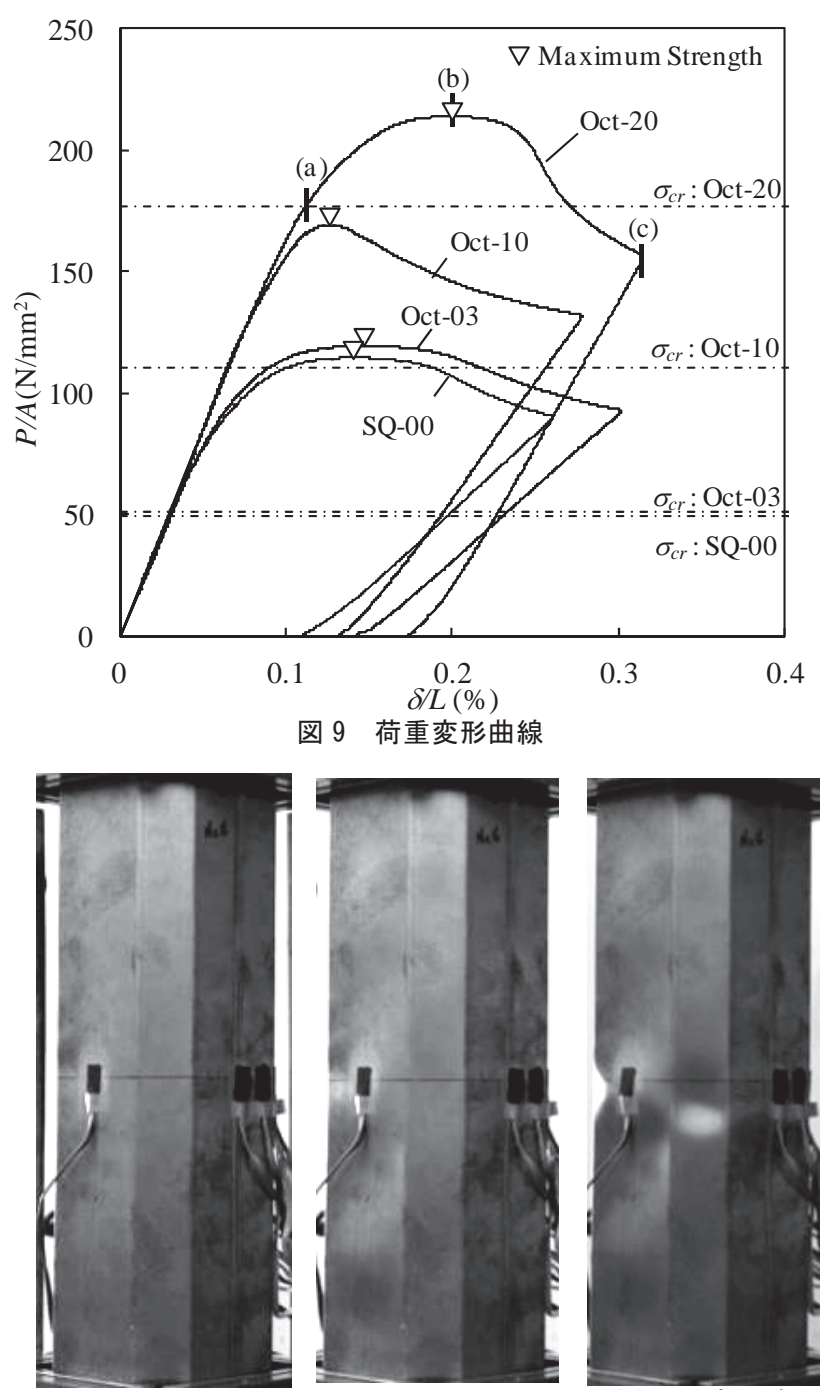

(a) 弾性座屈耐力時

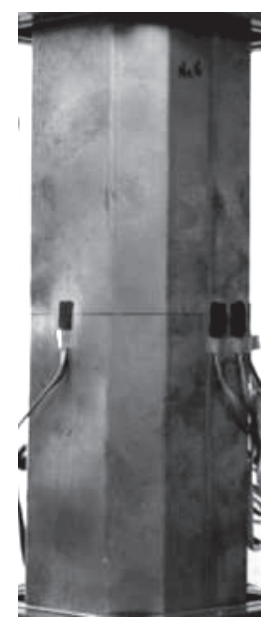

(b) 最大耐力時

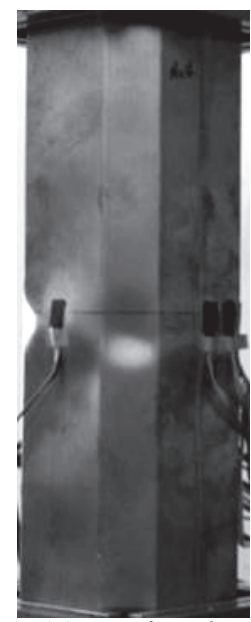

(c) 最大変形時

\section{図 10 試験体の座屈発生状況 (0ct-20 の場合)}

うに曲げ加工を行い, 開断面のコの字形状を有する形鋼を 2 つ製作 した．次にレーザー溶接機で突合せ溶接をおこない閉断面形状を有 する試験体とした。溶接に伴う突合せ部の形状や材質の変化が部材 の最大耐力に影響を及ぼさないように，溶接シームの位置は最大耐 力時に材軸方向の発生応力が最も小さくなる side plateの中心に配 した．また，溶接組立後に試験体の両端面を研磨し，端面を平坦に した. なお, 試験体製作の過程で生じる残留応力については, 有限 要素解析 (4 章)で残留応力を無視したモデルでの解析結果と実験結 果が概ね一致することを確認しており，本実験に用いた部材の最大 耐力に及ぼす影響は少なかったと考えている．また板要素の元たわ みが座屈後耐力に与える影響は小さい 10)ことから，本実験において 板要素の元たわみが座屈後耐力に及ぼす影響は少なかったものと推 察する.

表 1 には，鋼材の材料引張試験結果を示す. 本試験体に使用した 鋼材は, 引張強度が $400 \mathrm{~N} / \mathrm{mm}^{2}$ 級の薄鋼板である.JIS 規格の Z 2241 に基づき JIS5 号試験片を用いて材料引張試験を行い, 素材の機械 的特性を確認した.

図 7 には, 試験体のセットアップ概要を示す. 載荷装置は, 試験 体の両端と載荷板とがメタルタッチ寸ることで試験体に圧縮力が作 
用する機構を有する (図 7(a)). 試験体と載荷板の接触部近傍で端面 の形状不整に起因した局部変形が発生することを防止するために, 試験体の上下端から各々 $50 \mathrm{~mm}$ の範囲は side plate の面外変形を治 具で拘束した（図 7(b)).

図 8 には, 変位とひずみの計測計画を示す. 変位は, $25 \mathrm{~mm}$ ス卜 ロークの変位計を 4 箇所設置し, 上下の載荷板間の変位を計測した. ひずみは，試験体中央部に貼り付けたひずみゲージで計測した。な お, 溶接部の無い side plate の片方は, ひずみゲージを試験体の表 裏に貼り付け，板の局所的な曲げによるひずみの変化を観察できる 計測計画とした。

載荷は, 軸方向の単調圧縮載荷である。 まず予備載荷として弾性 局部座屈耐力の $50 \%$ の圧縮力を加え, 試験体の 4 面に貼り付けたひ ずみゲージで材軸方向に均一なひずみが生じていることを確認した. このときひずみの值に偏りがある場合は球座の位置を調整し, ひず みの差が士 $10 \%$ 以内に収まるようにした。 その後, 荷重をかけた状 態で球座を固定してから荷重が $1 \mathrm{kN}$ になるまで除荷をし, 本載荷を 開始した. 本載荷は変位制御で行い, 最大耐力の $80 \%$ まで部材耐力 が劣化した時点で除荷した.

\section{2 . 実験結果}

図 9 には, ロードセルで計測した荷重 $P$ と変位計で計測した変位 の平均值 $\delta$ の関係を示す. 実線は実験結果を表し, 一点鎖線は固有 值解析で計算した各試験体の弾性局部座屈耐力 $P_{c r}$ を表している. 各試験体とも載荷初期の段階で線形な荷重変形挙動を示したのち, $P_{c r}$ 近傍から剛性が徐々に低下し, 最大耐力に達して耐力低下に至 った。断面形状の違いが部材耐力に与える影響に着目すると, 角部 の幅 $W$ が大きい部材ほど高い部材耐力を発揮する傾向を示した.

図 10 には代表的な変形挙動の例として, Oct-20の（a）弾性座屈 耐力時, (b) 最大耐力時, (c) 最大変形時の写真を示寸. 図 10 の (a), (b)，(c) は，それぞれ図 9 中の(a)，(b)，(c) と対応している. 弾性局 部座屈耐力（図 9(a)）に達したとき, 試験体には目視で確認できる 局部変形は発生していなかった (図 10(a)). その後, 載荷が進むと 徐々に座屈変形が大きくなり, 最大耐力 (図 10(b)) に達した時点で は目視で確認できるほどの座屈変形が試験体の全面に発生した。 そ してさらに変形が進展すると, 耐力低下と共に試験体の中央部に変 形が局所化した（図 10(c)).

実験で計測した最大耐力 $P_{\max }$ と, 既往の評価式で計算した計算耐 力 $P_{u}$ との比較を行う. $P_{u}$ は, 断面を構成する板要素を全て単純支 持板と見なし, 各板要素の座屈後耐力を単純累加した值である.こ こでは, 部材断面を平坦な板要素（side plate, corner plate）と折 曲げ円弧部（R 部）に分割し, 各板要素および $\mathrm{R}$ 部の座屈後耐力を 単純累加した (式(2)). なお板要素は全て単純支持板とみなし, $\mathrm{R}$ 部 は全断面が有効で最外縁の曲げ半径が $2.0 \mathrm{~mm}$ の円弧形状の板と仮 定した。

$$
\begin{aligned}
& \mathrm{P}_{\mathrm{u}}=\mathrm{P}_{\mathrm{us}}+\mathrm{P}_{\mathrm{uc}}+\mathrm{P}_{\mathrm{uR}} \\
& \mathrm{P}_{\mathrm{us}}=\mathrm{n} \cdot \mathrm{b}_{\mathrm{s}} \cdot \mathrm{t} \cdot \rho \cdot \sigma_{\mathrm{y}} \\
& \mathrm{P}_{\mathrm{uc}}=\mathrm{n} \cdot \mathrm{b}_{\mathrm{c}} \cdot \mathrm{t} \cdot \rho \cdot \sigma_{\mathrm{y}} \\
& \mathrm{P}_{\mathrm{uR}}=\mathrm{A}_{\mathrm{R}} \cdot \sigma_{\mathrm{y}}
\end{aligned}
$$

表 2 最大耐力と計算耐力の比較

\begin{tabular}{|c|c|c|c|c|}
\hline & SQ-00 & 0ct-03 & 0ct-10 & 0ct-20 \\
\hline \hline $\mathrm{P}_{\max }(\mathrm{kN})$ & 36.8 & 37.5 & 51.4 & 61.0 \\
\hline $\mathrm{P}_{u}(\mathrm{kN})$ & 38.9 & 41.8 & 51.3 & 64.2 \\
\hline $\mathrm{P}_{\max } / \mathrm{P}_{u}$ & 0.95 & 0.90 & 1.00 & 0.95 \\
\hline Buckling mode & Local & Distortional & Local & Local \\
\hline
\end{tabular}

$$
\begin{array}{ll}
\text { ただし } & \\
P_{u s}, P_{u c}, P_{u R} & : \text { side plate, corner plate, } \mathrm{R} \text { 部の負担軸力 } \\
n & : \text { 板要素の枚数 }(=4) \\
b_{S}, b_{C} & : \text { side plate, corner plate } \text { 板幅 } \\
\rho & : \text { 低減係数 } \\
\sigma_{\mathrm{y}} & : \text { 鋼材の降伏強度 } \\
\mathrm{t} & : \text { 板厚 } \\
\mathrm{A}_{\mathrm{R}} & : \text { R 部の断面積 }
\end{array}
$$

ここに, 式(2)に示す $\rho$ は弾性局部座屈によって板要素内に無効領 域が生じる事を考慮するための低減係数である. 単純支持板の座屈 後耐力の評価については多くの研究がなされており, 評価式 10) 12) も多数提案されている. 本論では, 代表的な座屈後耐力の評価式と して AISI の設計指針 13)に収録されている式(3)で $\rho$ を求めた.なお, $\sigma_{c r_{-} k=4}$ は板要素を単純支持板と見なした場合の弾性局部座屈耐力で あり, 式(1)の $b_{1}$ を各板要素の板幅に置き換え, なお且つ $k=4$ とし て計算した弾性局部座屈耐力である.

$$
\begin{aligned}
\lambda \geqq 0.673 \quad \text { の場合 } \\
\rho=\frac{1-0.22 / \lambda}{\lambda} \\
\lambda<0.673 \quad \text { の場合 } \\
\rho=1
\end{aligned}
$$

ただし

$$
\lambda \text { : 一般化幅厚比 }\left(=\sqrt{ }\left(\sigma_{y} / \sigma_{c r_{-} k=4}\right)\right)
$$

表 2 には, 各試験体の最大耐力 $P_{\max }$ と, 式(2)で計算した計算耐 力 $P_{u}$ との比較を示寸. なお $\sigma_{y}$ の值については, 本実験に使用した 鋼材が明確な上降伏・下降伏を示さない忘力-ひ寸み関係を示した影 響で $0.1 \%$ オフセット耐力と $0.2 \%$ オフセット耐力で約 $5 \%$ の差が生 じたことを考慮し, 文献 14$)$ を参考に $0.1 \%$ オセット耐力を用いる こととした．表から， SQ-00 では， $P_{\max } / P_{u}=0.95$ となり実験結果 と概ね良い対応を示していることが分かる，隣接する板要素の幅が 異なる八角形断面の部材では, 角部幅が最も小さい Oct-03 では $P_{\max } / P_{u}=0.90$ となり SQ-00 を下回っている. Oct-03 ではゆがみ座 屈の発生を実験中に確認しており, 座屈モードの変化による影響で $P_{\max } / P_{u}$ が減少したと考えられる。一方, 角部幅の大きい Oct-10 お よび Oct-20 では $P_{\max } / P_{u}=1.00,0.95$ となり，いずれも $\mathrm{SQ}-00$ と同 等以上の值を示した. Oct-10 が SQ-00 や Oct-20 よりも高い值を示 した要因については, 次章で述べる.

以上から, ゆがみ座屈が発生したケースを除き, 板要素を単純支 持板とみな寸既往の耐力評価法は, 本実験に用いた部材の最大耐力 に対して概ね近い評価を与ることが分かった。 


\section{4. 八角形断面を構成する各板要素の負担軸力}

前章では, 隣り合う板要素の幅が異なる八角形断面の最大耐力が, 断面を構成する板要素を単純支持板とみな寸従来の設計法で評価し た計算耐力と概数近い值となることを明らかにした。一方で, 最大 耐力時に断面を構成する各板要素が負担する軸力と, 式(2),(3)で求 めた単純支持板の座屈後耐力との関係については不明なままである. そこで本章では, 有限要素解析 (FEA) を用いて各板要素が最大耐 力時に負担する軸力を定量化し, 隣り合う板要素の幅の違いが各板 要素の座屈後耐力に与える影響を明らかにする.

\section{1. 解析モデルの概要}

有限要素法を用いた大変形解析を行い, 隣り合う板要素の幅の違 いが各板要素の座屈後耐力に与える影響を調べた. 図 11 に解析モ デルの概要を示す. モデルは, 4 節点シェル要素を用いた有限要素 解析モデルである。ソルバーには汎用の FEM 解析ソフト (Marc2014r1)を使用した。解析モデルは, 部材長さ $400 \mathrm{~mm}$, 部材 幅 $100 \mathrm{~mm}$ の閉断面形状を有する。モデルの断面形状を試験体と同 様(図 5) とし, R 部は最外縁の曲げ半径が $2.0 \mathrm{~mm}$ の円弧形状を 4 等 分してモデル化している. 形状は試験体の上下端に設けた補剛冶具 を再現するために, 上下端から各々 $50 \mathrm{~mm}$ の領域で side plate の面 外变形を拘束した. 試験体の両端は, 図心位置と端部の節点を剛体 で接続し, 断面のゆがみ等が発生することを抑制した。形状初期不 整は, 文献 8)を参考に, 座屈固有值解析で求めた変形モードに基づ き最大変形量が板厚の $10 \%$ となるように与えた。図 $11(\mathrm{~b})$ には解析 で使用した鋼材の応力度・ひずみ度関係を示す，素材の応力度-ひず み度関係は, JIS 規格の Z2241 に基づき行った材料引張試験の結果

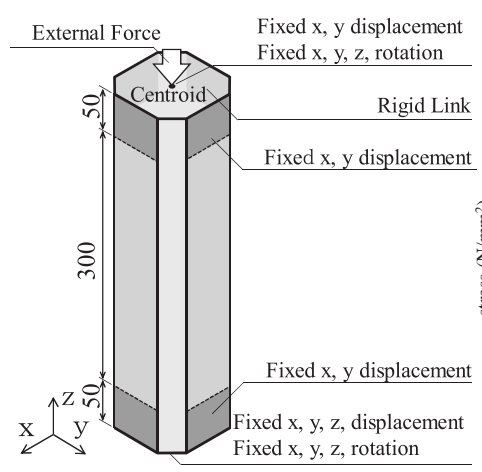

(a) 有限要素解析モデル概要

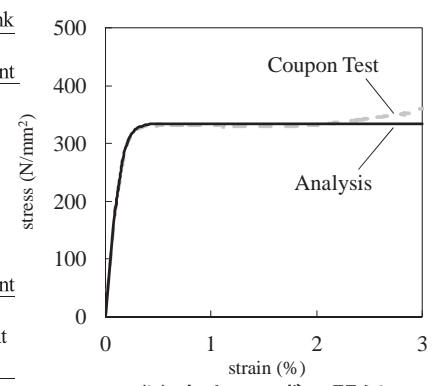

(b) 応カーひずみ関係

図 11 解析モデル概要

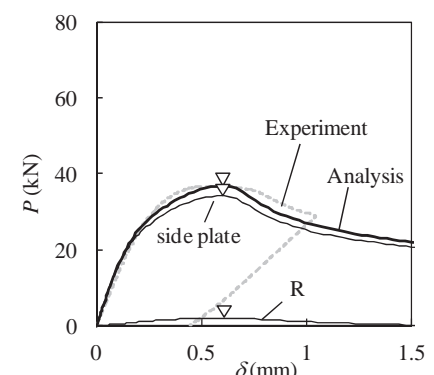

(a) $\mathrm{SQ}-00$

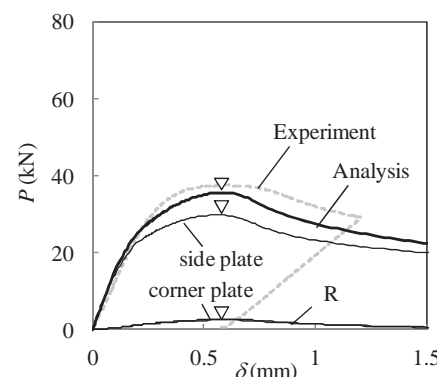

(b) 0 ct-03

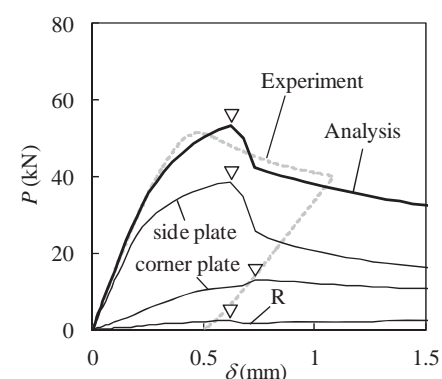

(c) 0 ct-10

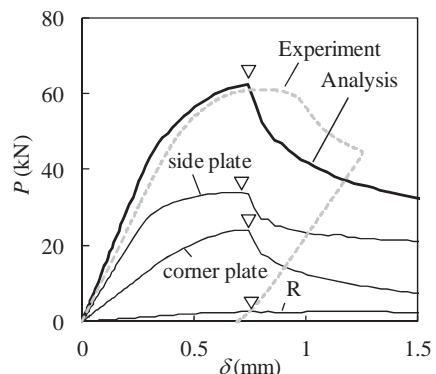

(d) 0 ct-20

図 12 FEA と実験結果の比較 

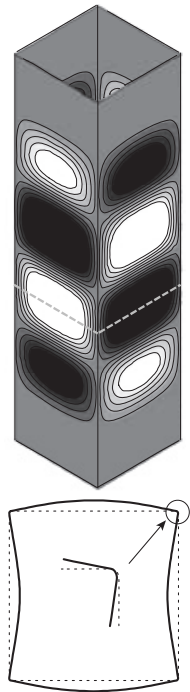

(a) $\mathrm{SQ}-00$

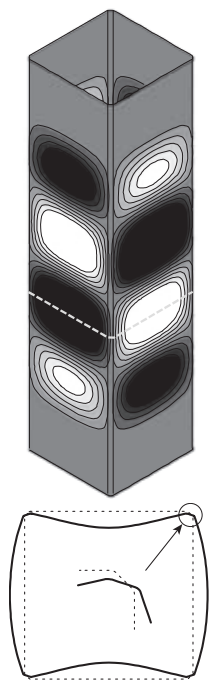

(b) 0 ct-03

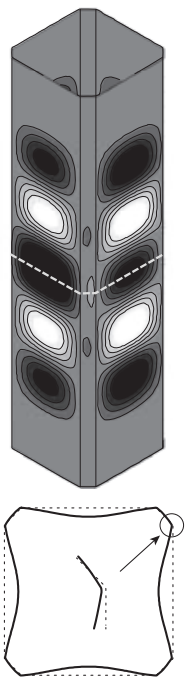

(c) 0 ct-10

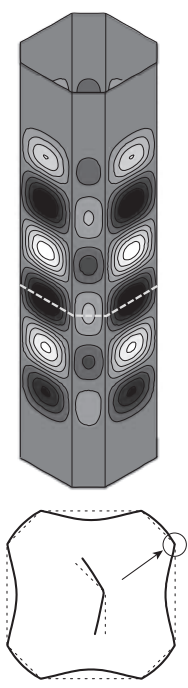

(d) $0 \mathrm{ct}-20$

\section{図 13 最大耐力時の面外変形}

では接合線の水平移動は認められず，接合線が回転して各板要素が 面外一凹凸に变形する局部座屈のモードが発生した。最大耐力時の 変形モードと 2 章の固有值解析から得た座屈モード (図 2) を比較 すると両者は類似の座屈モードを示したと分かる. 本解析モデルで は, 固有值解析で得られた座屈モードに基づき形状初期不正を与え ているため, 弾性座屈後は形状初期不正として与えた座屈モードの 変形が卓越し易いと考えられる. 各試験体とも最大耐力は弾性局部 座屈耐力を上回っており, 弾性座屈が生じたあと軸変形の増加とと もに固有モードの変形が卓越したことで, 固有值解析から得られた 座屈モードと類似の変形挙動を示したものと推察する.

\section{3. 板同士の相互拘束による負担軸力の変化}

図 14 には, 部材が最大耐力に達した時点で side plate および corner plate が負担する軸力 $P_{u s, \mathrm{FEA},} P_{u c, \mathrm{FEA}}$ を板要素の降伏耐力 $P_{y s}$, $P_{y c}$ (降伏応力度に各々の板要素の全断面積を乗じた值)で無次元化

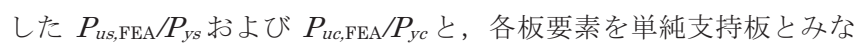
した場合の一般化幅厚比 $\lambda と の$ 関係を示寸. 図中の○とのは, 八角

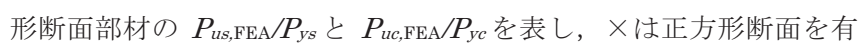
する SQ-00 の断面を構成する板要素が負担する軸力を表している. 破線は式(1)で計算した弾性局部座屈耐力であり, 実線は式(3)で計算

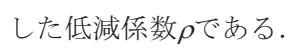

図から幅厚比の大きい SQ-00 の断面を構成する板要素や Oct-03,10,20の side plate では, 各板要素の負担する軸力が式(1) で計算した弾性局部座屈耐力を上回っていることが確認できる.こ れは, 弾性局部座屈が発生した後も断面内での応力再分配によって 板要素の負担応力が増加したためであり, 板要素が座屈後耐力を発 揮したとことを示す. 一方 corner plate のように幅厚比の小さい板 要素では, 各板要素の負担する軸力は式(1)で計算した弾性局部座屈 耐力を下回っており, 板要素は単純支持板と見なした場合の弾性局 部座屈耐力には達していない. $P_{u s, \mathrm{FEA}} / P_{y s}$ と $P_{u c, \mathrm{FEA}} / P_{y c}$ と式(3)で求 めた $\rho$ を比較すると, side plateおよび corner plate の負担軸力は $\rho$ を上回る場合もあれば，下回る場合もあった．

表 3 には, 式(2)で計算した $P_{u s}, P_{u c}$ と有限要素解析で計算した
$P_{u s, \mathrm{FEA},} P_{u c, \mathrm{FEA}}$ の值を示す. 表 3 中の括弧内の值は, $P_{u s, \mathrm{FEA}} / P_{u s}$ お よび $P_{u c, \mathrm{FEA}} / P_{u c}$ である.なお, 試験体と同じ素材特性を与えた正八 角形断面（ $W D=0.29 ）$ を有寸る部材の軸圧縮解析も実施したので, 結果を併せて示す．断面を構成する板要素を単純支持とみな寸事が できる SQ-00 と正八角形断面では， $P_{u s, \mathrm{FEA}} / P_{u s}$ は 0.94,0.95 となっ た.これに対して隣り合う板要素の幅が異なる八角形断面の場合, Oct-03 では $P_{u s, \mathrm{FEA}} / P_{u s}$ が SQ-00よりも減少し， $P_{u c, \mathrm{FEA}} / P_{u}$ は増加し ている.また Oct-10 と Oct-20では, $P_{u s, \mathrm{FEA}} / P_{u s}$ が SQ-00よりも増 加し, なおかつ $P_{u c, \mathrm{FEA}} / P_{u c}$ が SQ-00 と比べて減少しており, Oct-03 とは逆の傾向を示した.

この $P_{u s, \mathrm{FEA}} / P_{u s}$ と $P_{u c, \mathrm{FEA}} / P_{u c}$ の変動要因を分析するために, 式(3) を基に有限要素解析の結果から各板要素の等価な座屈係数 $k_{\mathrm{FEA}}$ を 逆算し, $W / D$ との関係を調べた. 参考として, 式(3)を展開して求め た等価な座屈係数 $k_{\mathrm{FEA}}$ の計算式を以下に示寸.

$$
\begin{aligned}
& \mathrm{k}_{\mathrm{FEA}}=\frac{12\left(1-v^{2}\right)}{\lambda_{\mathrm{FEA}}^{2} \pi^{2}} \frac{\sigma_{\mathrm{y}}}{\mathrm{E}} \\
& \lambda_{\mathrm{FEA}}=\frac{1}{2}\left(\frac{\mathrm{P}_{\mathrm{y}}}{\mathrm{P}_{\mathrm{u}, \mathrm{FEA}}}+\sqrt{\left(\frac{\mathrm{P}_{\mathrm{y}}}{\mathrm{Pu} \mathrm{u}_{\mathrm{FEA}}}\right)^{2}-0.88 \frac{\mathrm{P}_{\mathrm{y}}}{\mathrm{P}_{\mathrm{u}, \mathrm{FEA}}}}\right)
\end{aligned}
$$

ただし

$$
\begin{array}{ll}
k_{\mathrm{FEA}} & : \text { 等価な座屈係数 } \\
\lambda_{\mathrm{FEA}} & : \text { 等価な一般化幅厚比 } \\
P_{y} & : \text { 板要素の降伏耐力 }\left(P_{y s} \text { または } P_{y c}\right) \\
P_{u, \mathrm{FEA}} & : \text { 板要素の負担耐力 }\left(P_{u s, \mathrm{FEA}} \text { または } P_{u c, \mathrm{FEA}}\right)
\end{array}
$$

結果を図 15 に示す. ○が side plate の $k_{\mathrm{FEA}}$ を表し, ○が corner plate の k kEA を表し， ×が SQ-00 および正八角形断面の $k_{\mathrm{FEA}}$ を表 している.破線は，SQ-00の $k_{\mathrm{FEA}}$ の值(=3.48)を表している。 なお Oct-03 については corner plate の $P_{u c, \mathrm{FEA}}$ が $P_{y}$ を上回っており（図 14), 等価な座屈係数を計算することができないため, side plate の計算結果のみを図示した. 図から, 隣り合う板要素の幅が等しい SQ-00 および正八角形断面では， $k_{\mathrm{FEA}}=3.48,3.50$ となり概ね等しい 值を示した．なお， $k_{\mathrm{FEA}}$ が単純支持板の座屈係数 $(=4)$ を下回ったの は, 明確な降伏点を示さない鋼材の降伏強度を $0.1 \%$ オ七ット值で 工学的に定義したことの影響だと考えている. 一方, 隣接する板要 素の幅が異なる Oct-03, Oct-10, Oct-20 では $k_{\mathrm{FEA}}$ の值が SQ-00に 対して上下に変動しており, 断面形状の変化が板要素の境界条件に 影響を及ぼしたことが分かる。

表 3 板要素の負担耐力

\begin{tabular}{|c|c|c|c|c|}
\hline \multirow{2}{*}{ Specimen } & \multicolumn{2}{|c|}{ Nominal Strength $(\mathrm{kN})$} & \multicolumn{2}{|c|}{ FEA Result (kN) } \\
& $\begin{array}{c}\text { side plate } \\
\mathrm{P}_{\text {us }}\end{array}$ & $\begin{array}{c}\text { corner plate } \\
\mathrm{P}_{\text {uc }}\end{array}$ & $\begin{array}{c}\text { side plate } \\
\text { FEA } \mathrm{P}_{\text {us }}\end{array}$ & $\begin{array}{c}\text { corner plate } \\
\text { FEA } P_{\text {uc }}\end{array}$ \\
\hline SQ-00 & 36.38 & - & $34.14(0.94)$ & - \\
\hline Oct-03 & 36.20 & 2.40 & $29.74(0.82)$ & $2.49(1.03)$ \\
\hline Oct-10 & 35.54 & 12.54 & $38.56(1.08)$ & $11.26(0.90)$ \\
\hline Oct-20 & 34.06 & 27.20 & $33.88(0.99)$ & $24.02(0.88)$ \\
\hline 正八角形 & 31.36 & 31.36 & $29.86(0.95)$ & $29.86(0.95)$ \\
\hline
\end{tabular}

※SQ-00 は corner plate を有さないため”-” で標記 


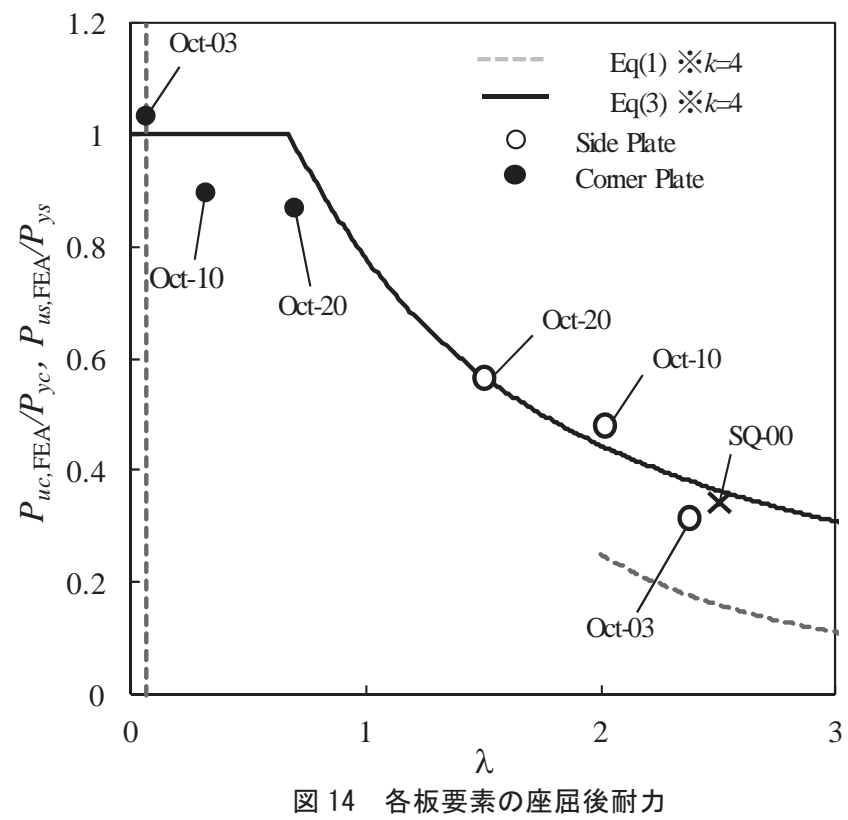

ここで, この座屈係数の変動の要因は, 隣接する板要素間の拘束 による影響であると考えられる，隣り合う板要素との接合線の移動 が生じること無く, 接合線の回転によって各板要素が凹凸に変形す する Oct-10 や Oct-20 では, side plate の側辺部(corner plate との 接合線)の回転変形が corner plateによって拘束されるため, side plate の座屈に対する抵抗は単純支持板とみなした場合よりも高く なる。このことは, 図 4 に示した座屈固有值解析の結果からも分か る. この端部拘束が作用したことで, 最大耐力時にも side plate の 負担軸力が上昇し, $P_{u s, \mathrm{FEA}}$ から逆算した座屈係数も SQ-00よりも高 くなった。なお，Oct-10 と Oct-20の kFEAを比較すると，Oct-10 の方が Oct-20よりも $k_{\mathrm{FEA}}$ は大きくなった. この傾向は, 2 章で述 べた断面形状の変化に伴う弾性局部座屈耐力の変動傾向とも一致し ており, 隣り合う板要素の幅の差が大きいほど, 板幅の小さい要素 が板幅の大きい要素を拘束する効果が大きくなると言える.一方で, side plateの側辺部の回転を corner plateが拘束するということは, side plate から corner plate に面外方向への曲げが作用することと 同義である.これは，図 13 において corner plateにも面外変形が 生じており，なおかつ図 14 において Oct-10 と Oct-20の $P_{u c, \mathrm{FEA}}$ が 式(3)の $\rho に$ 達していないという結果からも理解できる. corner plate の側辺部に板要素の面外変形を誘起する曲げが作用したこと で, corner plate の座屈係数は SQ-00 や正八角形断面よりも低くな った.

接合線の移動を伴うゆがみ座屈が生じ，なおかつ corner plate に 明確な面外変形が生じなかった Oct-03 では, side plate の $k_{\mathrm{FEA}}$ が SQ-00 に対して減少している. これは接合線の移動が生じたことで side plate の側辺部をともなうゆがみ座屈のモードが発生したこと による影響であると考えられ，前述の板要素同士の相互拘束は，部 材断面にゆがみ座屈が発生するケースでは成り立たない場合がある ことに注意する必要がある.

以上から, 隣り合う板要素の板幅が異なる八角形断面部材では, corner plate が side plate を拘束して side plate の座屈抵抗を高め る効果と, side plate が corner plateに対して面外方向への強制曲

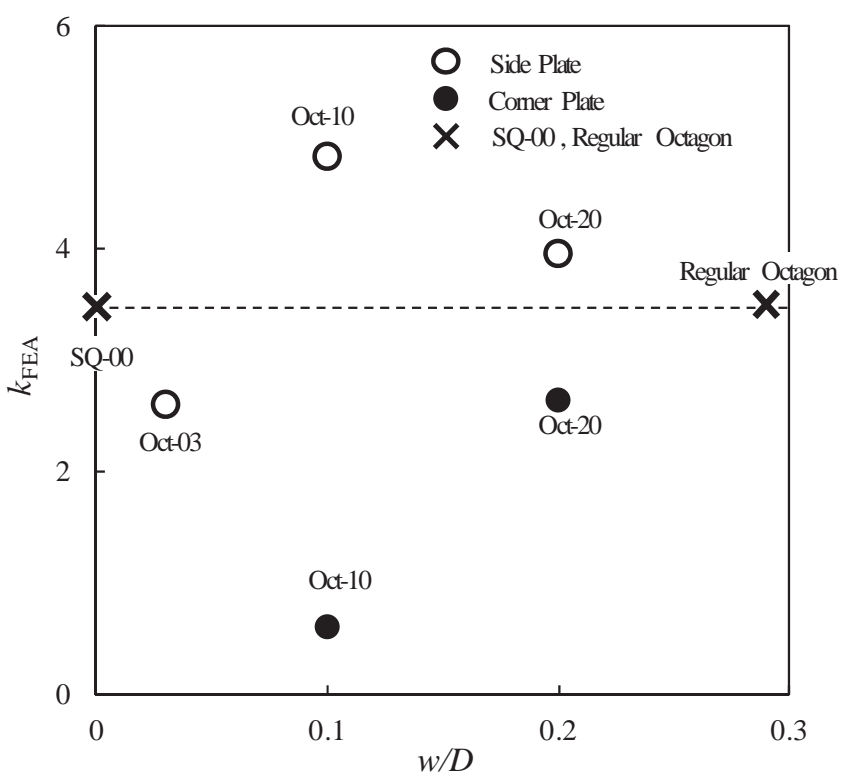

図 15 断面形状が各板要素の座屈後耐カに与える影響

げを与えることで corner plate の座屈抵抗を低下させる効果がある ことが明らかになった. Oct-10では, side plateの負担軸力の増加 分が corner plateの負担軸力の減少分を上回り, $P_{\max } / P_{u}$ (表 2)の值 が SQ-00 を上回った。 また Oct-20 では，前述の 2 つの効果が相殺 されたことで, $P_{\max } / P_{u}$ の值は SQ-00 と等しくなった.

\section{5. 結}

隣り合う板要素の板幅が異なる八角形断面部材について, 90 度の 回転対称の断面を有する八角形断面部材の座屈耐力に断面形状が及 ぼす影響を実験と数值解析で検討した。

まず，八角形断面を有する部材の局部座屈挙動に関する基本的な 性状を明らかにするため, 部材の断面形状をパラメータとした座屈 固有值解析を行った。一部の八角形断面において僅かな耐力低下が みられたものの, 隣接する板要素の幅厚比が異なる八角形断面は, 断面を構成する板要素を単純支持板とみなした場合の理論的な弾性 局部座屈耐力よりも高い弾性局部座屈耐力を有し，その上昇率は $w D=0.1$ 近傍で最大となった。 また八角形断面の弾性局部座屈耐力 の変動は，隣接する板要素間の拘束と，それに伴う座屈モードの変 化による影響を受ける傾向を示した。

次に，正方形および八角形断面部材の短柱圧縮実験を行い，部材 の最大耐力に断面形状が与える影響を調查した．部材幅が一定の場 合，本実験の範囲において八角形断面は総じて正方形断面よりも高 い最大耐力を発揮し, 角部幅 $W$ が大きいほど最大耐力が高くなる傾 向を示した，また，ゆがみ座屈が生じる場合を除き，断面を構成す る各板要素を単純支持板とみな寸従来の評価法は, 八角形断面部材 の最大耐力と良い対応を示寸ことが分かった。

最後に, 有限要素解析を用いて断面を構成する各板要素が負担す る軸力に部材の断面形状が与える影響を調べ, 部材耐力と各板要素 の負担耐力との関係を明らかにした。隣り合う板要素の幅が異なる 八角形断面では，板幅の大きい side plate は板幅の小さい corner plateによって側辺部を拘束されるため, side plate の座屈係数は正 方形断面よりも高くなる.一方で板幅の小さい corner plate は, side 
plate に作用する拘束力の反力によって面外一強制変形が生じるた め, 座屈係数が正方形断面よりも低くなる. これらの座屈係数が増 加・減少する効果が相殺されることで, 本実験に用いた八角形断面 部材の最大耐力と, 各板要素を単純支持板と見なした既往の耐力評 価法に基づく計算耐力は良い対応を示した。

\section{参考文献}

1）薄板軽量形鋼造建築物設計の手引き 第2版，技報堂出版, 2014

2）菅野良一：薄板軽量形鋼造における座屈設計, 建築技術, pp.125-127, 2013, 8

3) Bulson P.S. : The Strength of thin-walled tubes formed form flat elements, Int. J. Mech. Sci., vol.11, pp. 613-620, 1969

4) 右田泰弘, 青木徹彦, 福本唀士：多角形断面鋼柱の局部座屈に関寸る実 験的研究, 土木学会論文報告集, 第422号, pp.255-263, 1990, 10

5）小瀬古信博, 青木徹彦, 福本唀士：八角形断面鋼柱の局部座屈強度, 土 木学会論文報告集，第330号, pp.27-36, 1983, 2

6) Teng J.G., Smith S.T., Ngok L.Y. : Local Buckling of Thin-Walled polygonal Columns Subjected to Axial Compression or Bending, 2nd International Conference on advances in steel structure (ICASS 99), vols. 1 and 2,pp.109-115, 1999
7）木村衛 ： 金属部材を構成する板要素の有効幅についての一考察，日本建 築学会構造系論文集, 第673号, pp.437-442, 2012, 3

8) Li, Z., Schafer, B.W. : Buckling analysis of cold-formed steel members with general boundary conditions using CUFSM: conventional and constrained finite strip methods, Proceedings of the 20th Int;l. Spec. Conf. on Cold-Formed Steel Structures, pp.17-31, 2010

9) Hancock, G.J., Davids, A.J., Key, P.W., Lau, S.W., Rasmussen, K.R. Recent Developments in the Buckling and Nonlinear Analysis of Thin-Walled Structural Members, Thin-Walled Structure, Vol.9, pp.309-338, 1990

10）木村衛, 井上哲郎, 谷口元, 橋村徹, 小松健 : 薄板の座屈後耐力, 日本建 築学会構造系論文集, 第545号, pp.135-140, 2001, 7

11) Winter, G., Strength of Thin Steel Compression Flanges, Journal of Structural Engineering, ASCE, pp.527-576, 1946

12) Lind, N.C., Ravindra, M.K., Schorn, G. : Empirical Effective Width Formula, Proc. of ASCE, ST Div., Vol. 102, No. ST9, pp.1741-1751, 1976

13) North American Specification for the Design of Cold-Formed Steel Structural Members 2007 Edition, American Iron and Steel Institute, 2007

14）ステンレス建築構造設計基準・同解説 第2版，技報堂出版, 2001 


\title{
LOCAL BUCKLING STRENGTH OF UNIFORMLY COMPRESSED OCTAGONAL THIN WALLED SECTION MEMBERS
}

\section{Tomoki KOBASHI ${ }^{* 1}$, Nariaki NAKAYASU*2, Nobutaka SHIMIZU*2, Ryoichi KANNO*3 and Kikuo IKARASHI*4}

\author{
${ }^{* 1}$ Steel Structures Research Lab., Nippon Steel \& Sumitomo Metal Corporation, M. Eng. \\ Grad. Student, Dept. of Architecture and Building Engineering, Tokyo Institute of Technology \\ *2 Senior Researcher, Steel Structures Research Lab., Nippon Steel \& Sumitomo Metal Corporation, Dr. Eng. \\ ${ }^{* 3}$ Fellow, Research \& Development Center, Nippon Steel \& Sumitomo Metal Corporation, Ph. D. \\ ${ }^{*}$ Assoc. Prof., Dept. of Architecture and Building Engineering, Tokyo Institute of Technology, Dr. Eng.
}

Cold-formed steel members are widely applied in columns and other axial members in steel structures. One of the key issues in design of cold formed steel is local buckling strength under axial compression. As a means to avoid premature local buckling, we have paid on attention to the application of octagonal section members. The local buckling behavior of octagonal section members have been investigated by many researchers. However, these studies have focused mainly on regular octagonal sections and do not considered the restraining effect between adjacent plate elements. In this paper, we conducted numerical analysis (Finite Strip Analysis and Finite Element Analysis) and stab column tests, to investigate the elastic buckling strength and post buckling strength of octagonal section members where the adjacent plate elements have different width-thickness ratios.

First, we conducted Finite Strip Analysis to investigate the elastic buckling strength of octagonal section members. Through these numerical analysis, it was found that the octagonal section members generally showed higher strength than that of simply supported plate. These strength increases were depended on the difference of the width-thickness ratio between adjacent plate elements and the change of buckling mode.

Second, we examined the post buckling strength of octagonal section members through a stab-column compression test. We compared the post buckling strength of square section and that of octagonal section, and found that the post buckling strengths of octagonal section members was higher than those of square section members, when they have a same diameter. In addition, it was known that the post buckling strength of octagonal section members could be evaluated by the traditional effective-width method, where simply supported conditions were assumed.

Finally, we investigated the post buckling strength of each plate elements of octagonal section members whose adjacent plate elements have different widths by Finite Element Analysis. The post buckling strength of the plate elements with a large width was higher than of square section member. On the other hand, the post buckling strength of the plate elements with a small width was lower than that of square section member. These increase and decrease were dependent on the restraining effect between adjacent plate elements. Because of this trade-off effect between the adjacent plate elements, the effective width method, which regarded each plate elements as a simply supported plate, gave a good estimation about post buckling strength of the octagonal section members. 